\title{
Intake, digestibility, ingestive behavior and performance of goats fed spineless cactus genotypes resistant to carmine cochineal
}

[Consumo, digestibilidade, comportamento ingestivo e desempenho de caprinos alimentados com genótipos de palma forrageira resistentes à cochonilha-do-carmim]

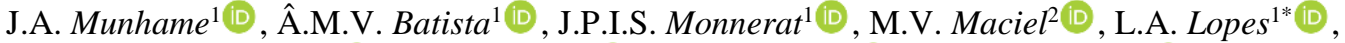 \\ T.G.P. Silva ${ }^{1}$, R.B. Andrade ${ }^{1}$ (D) D.B. Cardoso $^{3}$ (D) F.F.R. Carvalho ${ }^{1}$ (D) \\ ${ }^{1}$ Universidade Federal Rural de Pernambuco - UFRPE - Recife, PE, Brasil \\ ${ }^{2}$ Universidade Federal do Amazonas - Parintins, AM, Brasil \\ ${ }^{3}$ Universidade Federal do Agreste de Pernambuco - Garanhuns, PE, Brasil
}

\begin{abstract}
The objective was to evaluate the intake and digestibility of nutrients, ingestive behavior, and performance of goats fed with spineless cactus genotypes resistant to carmine cochineal (Miúda or Orelha de Elefante Mexicana (OEM). Thirty castrated male goats, without defined breed, aged 12 to 14 months, with an average body weight of $19.0 \pm 2.8 \mathrm{~kg}$, were distributed in a completely randomized design among three treatments (Control - Tifton hay, Miúda, and OEM) and ten replicates; the initial weight was considered as the covariate. The intake of organic matter (OM), neutral detergent fiber (NDF) was highest in the control treatment, while the intake of NFC was higher in the OEM diet. Treatments containing forage cactus showed the highest digestibility of DM, OM, and NFC. The animals fed the control diet spent more time on rumination and total chewing, but the time spent feeding or feeding efficiency, and performance did not differ. The use of spineless cactus genotypes resistant to carmine cochineal (Miúda and Orelha de Elefante Mexicana) in a diet for goats, in the amount of $450 \mathrm{~g} / \mathrm{kg}$ of DM does not interfere with the performance of the animals and improves the digestibility of OM and NFC.
\end{abstract}

Keywords: cactus, roughage, sustainability, ingestive behavior, NDF

\section{RESUMO}

Objetivou-se com o presente estudo avaliar o consumo e a digestibilidade de nutrientes, $o$ comportamento ingestivo e o desempenho de caprinos alimentados com genótipos de palma forrageira resistentes à cochonilha-carmim (miúda ou orelha-de-elefante-mexicana (OEM). Trinta cabritos machos, castrados, sem raça definida, com idades entre 12 e 14 meses e peso corporal médio de 19,0 2,8kg, foram distribuídos em delineamento inteiramente ao acaso, em três tratamentos (controle - feno de tifton; miúda e OEM) e 10 repetições; o peso inicial foi considerado a covariável. O consumo de matéria orgânica $(M O)$ e de fibra em detergente neutro $(F D N)$ foi maior no tratamento controle; enquanto a ingestão de CNF foi maior na dieta OEM. Tratamentos contendo palma forrageira apresentaram as maiores digestibilidades de $M S, M O$ e CNF. Os animais alimentados com a dieta controle gastaram mais tempo em ruminação e em mastigação total, mas o tempo gasto com alimentação ou a eficiência alimentar e o desempenho não diferiram. A utilização de genótipos de palma forrageira resistentes à cochonilha-carmim (miúda e orelha-de-elefante-mexicana) na dieta de caprinos, na quantidade de $450 \mathrm{~g} / \mathrm{kg}$ de MS, não interfere no desempenho dos animais e melhora a digestibilidade de MO e CNF.

Palavras-chave: cacto, feno, sustentabilidade, comportamento ingestivo, FDN

*Corresponding author: levi_auto@hotmail.com

Submitted: March 28, 2021. Accepted: June 11, 2021. 


\section{INTRODUCTION}

The forage cactus studies are now in semiarid regions as main forages cultivated for livestock, due to its characteristic resistance to hydric stress and advanceable nutritive value. However, carmine cochineal (Dactylopius sp) has been a limiting factor in the use of this forage, since, like other agricultural crops, pest infestations have led to reduced availability of forage, plant death, and the destruction of planted areas, with a direct influence on animal production (Monteiro et al., 2018). In areas where spineless cactus is cultivated for human consumption or cattle feed, farmers regard the species as a pest, and its control is considered a priority (Cruz-Rodriguez et al., 2016).

The best strategy for controlling this pest is to cultivate spineless cactus varieties that are resistant to cochineal carmine. This is also an environmentally friendly practice that is of great importance for smallholder farming because it dispenses with costly chemicals that pollute the environment and contributes to the sustainability of the production system (Silva et al., 2018). Resistant genotypes of spineless cactus include "Miúda" (Nopalea cochenillifera Salm Dyck) and "Orelha de Elefante Mexicana" (Opuntia strica Haw). According to Silva et al. (2015) the main differences among them are that Opuntia ficus indica presents higher values in levels of moisture, protein, lipids, soluble solids, minerals, and crude fiber in addition to length, width, and fresh weight when compared to Nopalea cochenillifera.

The chemical composition of spineless cactus varies: crude protein $(41.0-75.4 \mathrm{~g} / \mathrm{kg}$ of dry matter (DM)), neutral detergent fiber (236-277 $\mathrm{g} / \mathrm{kg}$ of DM), and non-fiber carbohydrate (460$528 \mathrm{~g} / \mathrm{kg}$ of DM) (Siqueira et al., 2017; Silva et al., 2018; Rocha Filho et al., 2021). These characteristics give the spineless cactus rapid ruminal degradability and high levels of total digestible nutrients (Batista et al., 2003). In addition, maybe an increase in microbial protein synthesis (Cardoso et al., 2019). However, it must be consumed in association with physically effective fiber sources (Soares et al., 2020).
As the diet adopted can directly or indirectly influence the final body weight, it was hypothesized that the varieties of spineless cactus resistant to carmine cochineal could maximize the intake and the digestibility of nutrients and, consequently, performance. Thus, the objective of this study was to evaluate the intake and nutrient digestibility, ingestive behavior, performance of goats fed with spineless cactus genotypes resistant to carmine cochineal 'Miúda' or 'Orelha de Elefante Mexicana'.

\section{MATERIAL AND METHODS}

This research was conducted in the goat sector of the Animal Science Department of the Federal Rural University of Pernambuco (UFRPE) in Recife, Brazil, located in the city of Recife, Pernambuco, Brazil, at the geographic coordinates of $8^{\circ} 04^{\prime} 03$ "S and $34^{\circ} 55^{\prime} 00^{\prime \prime} \mathrm{W}$. All procedures were carried out with the authorization of the Internal Committee on Ethics in the Use of Animals (CEUA/UFRPE), number license (142/2018).

Thirty castrated male goats, without defined breed, aged between 12 and 14 months, with an average body weight of $19.0 \pm 2.8 \mathrm{~kg}$, were distributed in a completely randomized design among three treatments and 10 replicates, using the initial weight as the covariate. Before the start of the experimental period, the animals were weighed, vaccinated against clostridiosis, and treated against endoparasites and ectoparasites. During the experimental period, the animals were kept in confinement in individual stalls. The experiment lasted 100 days, with 30 days of adaptation and 70 days of data collection.

The ingredients used in the experimental diets were Tifton 85 hay (Cynodon dactylon), "Miúda" (Nopalea cochenillifera Salm Dyck) or "Orelha de Elefante Mexicana (OEM)" (Opuntia strica Haw) spineless cactus, combined with soybean meal, ground corn, mineral salt and urea (Table 1). The experimental diets were isonitrogenated, aiming at an average daily gain of $150 \mathrm{~g} /$ day, according to the nutritional recommendations of the NRC (Nutrient..., 2007). The roughage:concentrate ratio of the diets was 60:40 (Table 2). 
Intake, digestibility...

Table 1. Chemical composition of ingredients on a dry matter basis (g/kg of DM)

\begin{tabular}{lccccc}
\hline \multicolumn{1}{c}{ Item } & $\begin{array}{c}\text { Tifton } \\
\text { hay }\end{array}$ & $\begin{array}{c}\text { Miúda } \\
\text { spineless } \\
\text { cactus }\end{array}$ & $\begin{array}{c}\text { OEM } \\
\text { spineless } \\
\text { cactus }\end{array}$ & $\begin{array}{c}\text { Soybean } \\
\text { meal }\end{array}$ & $\begin{array}{c}\text { Ground } \\
\text { corn }\end{array}$ \\
\hline Dry matter $^{\mathrm{a}}$ & 895.6 & 123.6 & 97.3 & 882.7 & 877.1 \\
Crude protein & 86.0 & 40.0 & 55.0 & 487.0 & 85.0 \\
Organic matter & 916.1 & 870.6 & 851.0 & 929.6 & 987.7 \\
Ash & 83.9 & 129.4 & 149 & 70.4 & 12.3 \\
Ether extract & 22.7 & 13.9 & 17.8 & 15.0 & 38.3 \\
NDFap & 669.4 & 252.8 & 198.1 & 134.6 & 146.8 \\
Acid detergent fiber & 336.2 & 137.1 & 95.3 & 116.8 & 24.5 \\
Lignin & 66.7 & 22.8 & 24.4 & 11.1 & 5.2 \\
NFC & 138.0 & 563.9 & 580.1 & 293.0 & 717.6 \\
Total carbohydrates & 807.4 & 816.7 & 778.1 & 427.6 & 864.4 \\
\hline
\end{tabular}

${ }^{a} \mathrm{~g} / \mathrm{kg}$ of fresh matter, OEM, Orelha de Elefante Mexicana, NDFap, neutral detergent fiber corrected for ash and protein, NFC, non-fiber carbohydrates.

Table 2. Proportion of ingredients and chemical composition of the experimental diets

\begin{tabular}{lccc}
\hline \multirow{2}{*}{ Ingredients $(\mathrm{g} / \mathrm{kg})$} & \multicolumn{1}{c}{ (g/kg DM) } & OEM \\
\cline { 2 - 3 } Tifton hay & Control & Miúda & 150 \\
Miúda spineless cactus & 600 & 150 & 0 \\
OEM spineless cactus & 0 & 450 & 450 \\
Ground corn & 0 & 0 & 273 \\
Soybean meal & 270 & 271 & 100 \\
Urea & 110 & 100 & 12 \\
Mineral mix & 5 & 14 & 15 \\
Chemical Composition $(\mathrm{g} / \mathrm{Kg} \mathrm{DM})$ & 15 & 15 & \\
Dry matter a & & & 190.3 \\
Organic matter & 890.8 & 234.8 & 895.3 \\
Crude protein & 924.0 & 904.2 & 143.2 \\
Ether extract & 142.1 & 141.8 & 23.4 \\
NDFap & 25.6 & 21.5 & 243.1 \\
Acid detergent fiber & 456.1 & 267.4 & 111.7 \\
Non-fiber carbohydrates & 221.1 & 130.4 & 485.8 \\
Total carbohydrates & 300.2 & 473.4 & 728.8 \\
Lignin & 756.3 & 740.8 & 23.5 \\
Ash & 42.6 & 22.8 & 104.7 \\
Total digestible nutrients & 76.0 & 95.8 & 719.3 \\
\hline
\end{tabular}

${ }^{a} \mathrm{~g} / \mathrm{kg}$ of fresh matter, OEM, Orelha de Elefante Mexicana, NDFap, neutral detergent fiber corrected for ash and protein.

The spineless cactus was crushed daily in a proprietary machine (Laboremus $®$, FP1001N) for cactus processing. The hay was crushed in a forage machine with an $8 \mathrm{~mm}$ sieve, in order to reduce selection by the animals. All ingredients were mixed to provide a complete feed. The diets were given ad libitum, twice a day, allowing a surplus of $15 \%$. During this period, feed and leftovers were weighed to determine feed intake. Leftover samples were taken twice a week during the experimental period (10\% of leftovers from each animal) and were frozen at $-20^{\circ} \mathrm{C}$ in hermetically sealed plastic bags.
For the digestibility assay samples of feces were collected directly from the animal's rectal ampulla three times a day, at different times, being at 6:00 am, 12:00 pm, and 4:00 pm on the first day; at $8 \mathrm{am}, 2 \mathrm{pm}$, and $8 \mathrm{pm}$ on the second day and at $10 \mathrm{am}, 4 \mathrm{pm}$ and $10 \mathrm{pm}$ on the third day. Samples of feed and leftovers were collected at the same time. Immediately after collection, the samples were weighed and predried in an oven with forced ventilation at $55^{\circ} \mathrm{C}$ for 72 hours. Samples composed of leftovers and feces of each animal were ground in a Willey-type Mill (TE-625, TECNAL, SP, 
Brazil), with a $1 \mathrm{~mm}$ and $2 \mathrm{~mm}$ screen respectively for subsequent chemical analysis and incubation for determination of indigestible neutral detergent fiber (NDFi).

To estimate the apparent digestibility, fecal dry matter production (FDMP) was calculated, using the NDFi as an internal indicator, after an incubation period of 288 hours in the rumen of an adult bovine (Valente et al., 2011). During the incubation period, the animal was fed with Tifton 85 hay and concentrate.

The dry matter (DM), organic matter (OM), crude protein $(\mathrm{CP})$, and ether extract $(\mathrm{EE})$ were determined according to the AOAC (Official..., 1990) using method number 967.03 for DM, 942.05 for OM, 981.10 for CP, and 920.29 for EE. Neutral detergent fiber (NDF) and acid detergent fiber (FDA) were determined according to the methodology proposed by Van Soest et al. (1991), while corrections for ash and protein were performed according to the methodology described by Mertens (2002) and Licitra et al. (1996), respectively.

Total carbohydrates (TC) were estimated using the equation proposed by Sniffen et al. (1992), and non-fiber carbohydrates (NFC) were estimated using the equation recommended by Hall (2000). The equation described by Weiss (1999) was used to estimate total digestible nutrients (TDN).

Behavioral parameters were observed using scan sampling, as proposed by Martin \& Bateson (1993), at 10-minute intervals for 24 hours (Johnson and Combs, 1991). The behavioral variables observed were Feeding, Ruminating, and Idle times. The feed and rumination efficiencies of DM and NDF were calculated by dividing the intake of each of these nutrients by the total feeding time (feed efficiency) and rumination time (rumination efficiency), respectively.

To evaluate their performance, the animals were weighed at the beginning and end of the experimental period. Total weight gain (TWG) was calculated as the difference between the final body weight (FBW) and initial body weight $(\mathrm{IBW}):$ TWG $=(\mathrm{FBW}-\mathrm{IBW})$, average daily gain $(\mathrm{ADG})=(\mathrm{TWG} /$ days of the trial period $)$.
The feed efficiency (FE) was determined as the ratio between TWG and DMI, FE $=(\mathrm{ADG} / \mathrm{DM}$ intake).

The experimental design was completely randomized, according to the model below:

$$
y i j=m+t i+\beta(X i j-X)+e i j
$$

Where: yij = value observed in the experimental unit that received treatment $\mathrm{I}$, replicate $\mathrm{j} ; \mathrm{m}=$ general effect of the mean; ti $=$ effect of treatment I; $\beta(\mathrm{Xij}-\mathrm{X})=$ covariate effect (initial body weight), eij = random error (residual). For statistical analysis, the statistical package SAS version 9.3 (2011) was used, with significance set at $5 \%$, and initial body weight as the covariate. An analysis of variance was performed and when necessary, the means were compared by the Tukey test at the same level of significance.

\section{RESULTS}

There was no significant difference $(P>0.05)$ in the dry matter (DM), digestible organic matter (DOM), or crude protein (CP) intake between treatments. However, there was a significant difference $(P<0.05)$ in intake of organic matter (OM), neutral detergent fiber (NDF), NDF\% of body weight $(\mathrm{BW})$, and non-fiber carbohydrates (NFC) (Table 3). The mean intake of DM (g/day and $\% \mathrm{BW}$ ), CP, and DOM was $658 \mathrm{~g} / \mathrm{day}, 3 \%$, $95.3 \mathrm{~g} / \mathrm{day}$, and $466.7 \mathrm{~g} /$ day, respectively.

The apparent digestibility of nutrients was influenced by diets $(P<0.05)$, except for $\mathrm{CP}$ and NDF digestibility $(P>0.05)$, with averages of 758 and $685 \mathrm{~g} / \mathrm{kg} \mathrm{DM}$, respectively (Table 3). The diets containing spineless cactus showed higher digestibility coefficients for DM, OM, and NFC. There was an effect $(P>0.05)$ of the diets on ingestive behavior, for the variables rumination time and chewing time, with higher values observed in animals fed with the control diet, while the idle time and the efficiency of the rumination rates were higher in animals fed diets containing the Miúda and OEM genotypes. While there was no influence $(P>0.05)$ of the diets on the feeding time, feeding efficiency of $\mathrm{DM}$, or rumination efficiency of $\mathrm{DM}$, with averages of $3.1 \mathrm{~h} /$ day, $0.22 \mathrm{~g} \mathrm{DM} / \mathrm{h}$, and $0.15 \mathrm{~g}$ $\mathrm{DM} / \mathrm{h}$, respectively (Table 4 ). 
Intake, digestibility...

Table 3. Intake and digestibility of nutrients in of goats fed with spineless cactus genotypes resistant to carmine cochineal

\begin{tabular}{|c|c|c|c|c|c|}
\hline \multirow{2}{*}{ Item } & \multicolumn{3}{|c|}{ Treatments } & \multirow{2}{*}{ SEM } & \multirow{2}{*}{$P$-value } \\
\hline & Control & Miúda & OEM & & \\
\hline \multicolumn{6}{|l|}{ Intake (g/day) } \\
\hline Dry matter & 704 & 603 & 668 & 27.422 & 0.078 \\
\hline Organic matter & $651.0 \mathrm{a}$ & $547.0 \mathrm{~b}$ & $601.0 \mathrm{ab}$ & 25.275 & 0.045 \\
\hline Crude protein & 104.0 & 89.0 & 97.0 & 3.941 & 0.071 \\
\hline NDFap & $290.0 \mathrm{a}$ & $167.0 \mathrm{~b}$ & $161.0 \mathrm{~b}$ & 14.216 & $<.0001$ \\
\hline Non-fiber carbohydrates & $236.0 \mathrm{~b}$ & $275.0 \mathrm{~b}$ & $326.0 \mathrm{a}$ & 13.471 & 0.001 \\
\hline Digestible organic matter & 487.0 & 446.0 & 467.0 & 0.020 & 0.458 \\
\hline \multicolumn{6}{|l|}{ Intake $(\% B W)$} \\
\hline Dry matter & 3.1 & 2.8 & 3.0 & 0.064 & 0.080 \\
\hline NDFap & $1.28 \mathrm{a}$ & $0.77 b$ & $0.73 b$ & 0.051 & $<.0001$ \\
\hline \multicolumn{6}{|c|}{ Total apparent digestibility $(\mathrm{g} / \mathrm{kg})$} \\
\hline Dry matter & $705.8 b$ & $752.8^{\mathrm{a}}$ & $724.5 \mathrm{ab}$ & 7.393 & 0.036 \\
\hline Organic matter & $743.9 b$ & $790.9^{\mathrm{a}}$ & $778.9 \mathrm{a}$ & 6.324 & 0.003 \\
\hline Crude protein & 755.4 & 766.2 & 742.9 & 6.656 & 0.413 \\
\hline NDFap & 691.7 & 667.3 & 683.6 & 7.071 & 0.308 \\
\hline Non-fibrous carbohydrates & $758.6 \mathrm{~b}$ & $870.0 \mathrm{a}$ & $848.7 \mathrm{a}$ & 11.614 & $<.0002$ \\
\hline
\end{tabular}

SEM, standard error of the mean, OEM, Orelha de Elefante Mexicana, NDFap, neutral detergent fiber corrected for ash and protein.

Digestible organic matter $(\mathrm{DOM})=\mathrm{OM}$ intake*digestibility of OM.

Averages in rows followed by different letters are statistically different by the Tukey test at $5 \%$ probability.

Table 4. Ingestive behavior of goats fed with spineless cactus genotypes resistant to carmine cochineal

\begin{tabular}{lccccc}
\hline \multirow{2}{*}{\multicolumn{1}{c}{ Item }} & \multicolumn{3}{c}{ Treatments } & \multirow{2}{*}{ SEM } & $P$-value \\
\cline { 2 - 5 } & Control & Miúda & OEM & & 0.195 \\
Feeding time (h/day) & 3.63 & 2.78 & 3.12 & 0.189 & 0.195 \\
Rumination time (h/day) & $6.22 \mathrm{a}$ & $4.37 \mathrm{~b}$ & $4.37 \mathrm{~b}$ & 0.325 & 0.021 \\
Idle time (h/day) & $14.15 \mathrm{~b}$ & $16.87 \mathrm{a}$ & $16.52 \mathrm{a}$ & 0.386 & 0.004 \\
Total chewing time (h/day) & $9.85 \mathrm{a}$ & $7.14 \mathrm{~b}$ & $7.48 \mathrm{~b}$ & 0.385 & 0.004 \\
Feeding efficiency (g DM/h) & 0.20 & 0.25 & 0.24 & 0.017 & 0.514 \\
Rumination efficiency (g DM/h) & 0.12 & 0.17 & 0.16 & 0.013 & 0.246 \\
Rumination efficiency (g NDF/h) & $0.41 \mathrm{~b}$ & $1.09 \mathrm{a}$ & $1.04^{\mathrm{a}}$ & 0.110 & 0.009 \\
\hline
\end{tabular}

SEM, standard error of the mean, OEM, Orelha de Elefante Mexicana.

Averages in rows followed by different letters are statistically different by the Tukey test at $5 \%$ probability.

No effects $(P>0.05)$ were observed for the performance of the animals, with a mean of $24.6 \mathrm{~kg}, 4.9 \mathrm{~kg}, 70.7 \mathrm{~g}$, and 0.10 , for final body weight, total weight gain, average daily gain (ADG) and feed efficiency, respectively (Table 5).

Table 5. Animal performance of goats fed with spineless cactus genotypes resistant to carmine cochineal

\begin{tabular}{lccccc}
\hline \multirow{2}{*}{\multicolumn{1}{c}{ Item }} & \multicolumn{3}{c}{ Treatments } & \multirow{2}{*}{ SEM } & \multirow{2}{*}{$P$-value } \\
\cline { 2 - 4 } & Control & Miúda & OEM & & \\
\hline Initial body weight $(\mathrm{kg})$ & 19.6 & 19.5 & 19.6 & 0.516 & -- \\
Final body weight $(\mathrm{kg})$ & 25.5 & 23.5 & 24.8 & 0.847 & 0.127 \\
Total weight gain $(\mathrm{kg})$ & 5.9 & 3.6 & 5.2 & 0.519 & 0.127 \\
Average daily gain (g/day) & 85 & 52 & 75 & 7.413 & 0.127 \\
Feed efficiency & 0.11 & 0.08 & 0.11 & 0.008 & 0.236 \\
\hline
\end{tabular}

SEM, standard error of the mean, OEM, Orelha de Elefante Mexicana.

Averages in rows followed by different letters are statistically different by the Tukey test at $5 \%$ probability. 


\section{DISCUSSION}

The spineless cactus genotypes that are resistant to carmine cochineal showed minimal differences in chemical composition (Table 1) and similar levels of acceptance by the animals in the diets. This is consistent with Vieira et al. (2008), who found that including spineless cactus with $150 \mathrm{~g} / \mathrm{kg}$ of Tifton hay in a goat diet led to similar DM intake compared to the control treatment. No differences were reported between dry matter intake in diets containing Miúda and OEM n genotypes in Saanen goats (Goés Neto et al., 2021) and dairy cows Monteiro et al. (2018).

Regardless of genotype, the spineless cactus diets resulted in a lower intake of NDF and NDF\% BW, about the control, due to the lower NDF content in these diets (Table 2). Literature has reported an increase in DM intake as a function of a reduction in dietary NDF (Lins et al., 2016; Oliveira et al., 2017), but this was not observed in the present study. However, the spineless cactus likely provokes ruminal distension, thus limiting intake, due to the low DM content of the diet (Silva et al., 2018).

The reduction in the intake of organic matter $(\mathrm{OM})$ in the Miúda treatment can be attributed to the high ash content of the diet $(+20.6 \%$ in comparison to the control) (Table 2), as well as the increase in intake of NFC in the OEM diet, as a result of the greater availability about the other diets.

The digestibility of a food is closely related to the chemical composition, being the fibrous fraction that exerts greater influence (McDonald et al., 2011). In general, the lower apparent digestibility values observed in the control diet compared to the spineless cactus-containing diets can be explained by the fact that fiber-rich diets reduce efficiency through an increase in caloric increment, which is probably a function of increasing feeding and rumination time (Van Soest, 1994). However, the high digestibility values of DM and OM observed in treatments with Miúda and OEM spineless cactus can be attributed to the higher levels of NFC and low NDF levels present in these cacti. High levels of NFC may also result in a decrease in $\mathrm{pH}$ in the rumen, reducing cellulolytic activity (Porto Filho et al., 2020). However, Siqueira et al. (2018) reported that the ruminal $\mathrm{pH}$ reduction in forage cactus-containing diets may not be sufficient to limit or inhibit NDF digestibility. It is noteworthy that a large portion of the spineless cactus NFC consists of pectin, $\beta$-glucans, and fructosanas, and their ruminal fermentation has the advantage of producing a smaller quantity of lactic acid (Batista et al., 2003), reducing the risk of the decline in ruminal $\mathrm{pH}$.

In another study, Monteiro et al. (2018) when comparing two genotypes of spineless cactus, found that the digestibility of the nutrients DM, $\mathrm{OM}, \mathrm{CP}$, and NFC did not differ between diets containing Miúda and OEM genotypes for dairy cows, attributing this to the chemical similarity between the varieties evaluated. Siqueira et al. (2017) evaluated the inclusion of the Miúda spineless cactus replacing Tifton hay in the diet of cattle and also observed an increase in the digestibility of DM and OM.

The succulence of spineless cactus diets and their lower percentage of NDF facilitate chewing and swallowing, as well as reducing the stimulation of regurgitation that precedes remastigation. A longer idle time was observed in animals receiving diets containing spineless cactus in relation to the control diet, despite the similarity in feeding time for all treatments, due to the reduction in rumination time caused by the lower NDF content present in the diet (Table 2). Rumination activity is influenced by the nature of the diet, mainly by the NDF levels (Van Soest, 1991). In the present study, the rumination time ranged from $4.37 \mathrm{~h} /$ day $(\mathrm{OEM})$ to $6.22 \mathrm{~h} /$ day (Control), illustrating that the higher the physically effective fiber content, the longer the time spent in rumination.

Likely, the similar nutrient flow to the muscle and adipose tissues from DM and DOM intake did not differentiate anabolism and fat deposition in animals with different treatments. The diets were formulated to meet the nutritional requirements of animals for a gain of $150 \mathrm{~g} /$ day with an intake of $720 \mathrm{~g}$ of DM, $480 \mathrm{~g}$ of TDN, and $108 \mathrm{~g}$ of $\mathrm{CP}$ according to NRC (Nutrient..., 2007); where only the control treatment had expected intake. Although there were no differences in animal performance, the weight gain of goats fed with the OEM spineless cactus of $85 \mathrm{~g}$ was $38 \%$ higher when compared to those fed with the Miúda of $52 \mathrm{~g}$. However, regardless of diet, the animals did not reach the expected 
performance responses, due to the low genetic potential of the animals for weight gain, age, and lack of adaptation of the animals to the confinement environment, due to the extensive breeding system in which animals were raised before the experimental period (Lima Júnior et al., 2015).

\section{CONCLUSION}

The use of spineless cactus genotypes resistant to carmine cochineal (Miúda and Orelha de Elefante Mexicana) in a diet for goats, in the amount of $450 \mathrm{~g} / \mathrm{kg}$ of DM does not interfere with the performance of the animals and improves the digestibility of OM and NFC. So, these cactus are important forage resources for semi-arid regions.

\section{ACKNOWLEDGMENT}

This work was supported by the Foundation for the Support of Science and Technology of Pernambuco - FACEPE.

\section{REFERENCES}

BATISTA, A.M.V.; MUSTAFA, A.F.; MCALLISTER, T. et al. Effects of variety on chemical composition, in situ nutrient disappearance and in vitro gas production of spineless cacti. J. Sci. Food Agric., v.83, p.440445, 2003.

CARDOSO, D.B.; CARVALHO, F.F.R.; MEDEIROS, G.R. et al. Levels of inclusion of spineless cactus (Nopalea cochenillifera Salm Dyck) in the diet of lambs. Anim. Feed Sci. Technol., v.247, p.23-31, 2019.

CRUZ-RODRIGUEZ, J.A.; GONZALEZMACHORRO, E.; VILLEGAS GONZALEZ, A.A. et al. Autonomous biological control of Dactylopius opuntiae (Hemiptera: Dactyliiopidae) in a prickly pear plantation with ecological management. Environ. Entomol., v.45, p.642-648, 2016.

GOÉS NETO, P.E.; SILVA, J.G.M.; AGUIAR, E.M. et al. Native and introduced forage cacti in Saanen dairy goat diets. Acta Sci. Anim. Sci., v.43, p.51029, 2021.
HALL, M.B. Neutral detergent-soluble carbohydrates. Nutritional relevance and analysis. Gainesville: University of Florida, 2000. p.76.

JOHNSON, T.R.; COMBS, D.K. Effects of prepartum diet, inert rumen bulk, and dietary polyethylene glycol on dry matter intake of lactating dairy cows. J. Dairy Sci., v.74, p.933944, 1991.

LICITRA, G.; HERNANDEZ, T.M.; VAN SOEST, P.J. Standardization of procedures for nitrogen fractionation of ruminant feed. Anim. Feed Sci. Technol., v.57, p.347-358, 1996.

LIMA JÚNIOR, D.M.; FERREIRA, B.F.; RIBEIRO, M.N.; MONTEIRO, P.B.S. Feno de maniçoba na alimentação de caprinos Moxotó. Semin. Cienc. Agr., v.36, p.2211-2222, 2015.

LINS, S.E.B.; PESSOA, R.A.S.; FERREIRA, M.D.A. et al. Spineless cactus as a replacement for wheat bran in sugar cane-based diets for sheep: intake, digestibility, and ruminal parameters. Rev. Bras. Zootec., v.45, p.26-31, 2016.

MARTIN, P.; BATESON, P. Measuring behavior: an introductory guide. 2.ed. New York: Cambridge University Press, 1993.

MCDONALD, P.; EDWARDS, R.A.; GREENHALGH, J.F.D. et al. Animal nutrition. 7.ed. Harlow, England: Pearson education limited, 2011.

MERTENS, D.R. Gravimetric determination of amylase treated neutral detergent fiber in feeds with refluxing in beaker or crucibles: collaborative study. J. AOAC Int., v.85, p.12171240, 2002.

MONTEIRO, C.C.F.; FERREIRA, M.A.; VÉRAS, A.S.C. et al. A new cactus variety for dairy cows in areas infested with Dactylopius opuntiae. Anim. Prod. Sci., v.59, p.479-485, 2018.

NUTRIENT requirements of small ruminants: sheep, goats, cervids, and new world camelids. Washington: National Academies Press, 2007.

OFFICIAL methods of analysis, Virginia: AOAC, 1990. 
OLIVEIRA, J.P.F.; FERREIRA, M.A.; ALVES, A.M.S.V. et al. Spineless cactus as a replacement for sugarcane in the diets of finishing lambs. Trop. Anim. Health Prod., v.49, p.139-144, 2017.

PORTO FILHO, J.M.; COSTA, R.G.; RIBEIRO, N.L. et al. Study of morphometric and ruminal parameters in santa inês sheep fed spineless cactus (Opuntia ficus-indica, MILL). Arq. Bras. Med. Vet. Zootec., v.72, p.2045-2052, 2020.

ROCHA FILHO, R.R.; SANTOS, D.C.; VÉRAS, A.S.C. et al. Can spineless forage cactus be the queen of forage crops in dryland areas?. J. Arid Environ., v.186, p.104426, 2021.

SILVA, A.P.G.; SOUZA, C.C.E.; RIBEIRO, J.E.S. et al. Características físicas, químicas e bromatológicas de palma Gigante (Opuntia fícus indica) e Miúda (Nopalea cochenillifera) oriundas do estado da paraíba. Rev. Bras. Tecnol. Agroind., v.9, p.2, 2015.

SILVA, R.C.M.A.; FERREIRA, M.A.; OLIVEIRA, J.C.V. et al. Orelha de Elefante Mexicana (Opuntia stricta [Haw.] Haw.) spineless cactus as an option in crossbred dairy cattle diet. South Afr. J. Anim. Sci., v.48, p.516$525,2018$.

SIQUEIRA, M.C.B.; FERREIRA, M.A.; MONNERAT, J.P.I.S. et al. Nutritional performance and metabolic characteristics of cattle fed spineless cactus. J. Agric. Sci. Technol, v.20, p.13-22, 2018.

SIQUEIRA, M.C.B.; FERREIRA, M.A.; MONNERAT, J.P.I.S. et al. Optimizing the use of spineless cactus in the diets of cattle: total and partial digestibility, fiber dynamics and ruminal parameters. Anim. Feed Sci. Technol., v.226, p.56-64, 2017.
SNIFFEN, C.J.; O'CONNOR, J.D.; VAN SOEST, P.J. A net carbohydrate and protein system for evaluating cattle diets. II. Carbohydrate and protein availability. J. Anim. Sci., v.70, p.3562-3577, 1992.

SOARES, P.C.; GOUVEIA, L.N.F.; SILVA, T.G.P. et al. Metabolic dynamics of native lambs fed with Tifton 85 hay or Maniçoba hay associated with the spineless cactus. Arq. Bras. Med. Vet. Zootec., v.72, p.215-223, 2020.

STATISTICAL analisis sistem institute. SAS 9.3 user's guide. Cary: Statistics SAS Institute Inc., 2011.

VALENTE, T.N.P.; DETMANN, E.; QUEIROZ, A.C. et al. In situ estimation of indigestible compounds contents in cattle feed and feces using bags made from different textiles. Rev. Bras. Zootec., v.40, p.666-833, 2011.

VAN SOEST P.J.; ROBERTSON, J.B.; LEWIS, B.A. Methods for dietary fiber, neutral detergent fiber, and nonstarch polysaccharides in relation to animal nutrition. J. Dairy Sci., v.74, p.35833597, 1991.

VAN SOEST, P.J. Nutritional ecology of the ruminant. 2.ed. [Ithaca]: Cornell University, 1994. 476p.

VIEIRA, E.L.; BATISTA, A.M.V.; GUIM, A. et al. Effects of hay inclusion on intake, in vivo nutrient utilization and ruminal fermentation of goats fed spineless cactus (Opuntia ficus indica Mill) based diets. Anim. Feed Sci. Technol., v.141, p.199-208, 2008.

WEISS, W.P. Energy prediction equations for ruminant feeds. In: CORNELL NUTRITION CONFERENCE FOR FEED MANUFACTURERS, 1999, Ithaca. Proceedings... Ithaca: Cornell University, 1999. p.176-185. 